\title{
From the Director's desk
}

I was first introduced to the Fauna Preservation Society (as it then was) some 12 years ago by John Burton, who had recently been appointed Executive Secretary. John gave me little choice, I had to join, and l've paid my dues more or less on time ever since. During that period I've done a few bits and pieces to help the Society including taking part in three Great Bird Races (which was fun) and attempting to raise sponsorship money (which was definitely not fun). I've given a couple of talks, but basically I've been a typical member: supporting a good cause and doing a bit to help when I've had the time. Now I've become the Fauna and Flora Preservation Society's (as it now is) first Executive Director, which is a considerable change from my existence over the past 20 or so years.

During that time I've written and edited rather a lot of books on birds and wildlife. I've written television programmes and even appeared on a few. I've started a couple of businesses selling wildlife in one form or another and, if I had to sum it all up, I'd say that I was a sort of wildlife entrepreneur. I, once, even applied for a job as assistant warden on a national nature reserve. Needless to say I failed because I didn't have an honours degree in zoology, or the ability to maintain a Land Rover. I understand that the latter is no longer necessary!

l've spent a lot of time wondering why the Society decided that they needed someone like me. After all, my practical conservation work consists of putting up nest boxes and ensuring that my cats are full of food during the breeding season. I suppose the wildlife tours that l've organized and led could be called 'educational', but it's a surreptitious form of education at best. Frankly I can only presume that someone who can identify birds, a few large mammals and a handful of flowers also has the naivety to see the wood for the trees and get down to some serious conservation.

Just a few weeks after joining the Society I ran into the wildlife artist David Shepherd for the first time in several years. Always a man of action, David had decided to donate the rest of his working life to conserving the wildlife that has been responsible for his success. Repaying the debt as it were. If it sounds a bit pretentious, I apologize, but I must say I feel the same. Wildlife has provided me with a living and a great deal of enjoyment for the past 20 years, it is perhaps time that I made repayment.

Well that's all about me. Now what about you? As members of the FFPS you are clearly keen on conservation and want to get things done to save the other life forms that share our planet. I may be the Executive Director, but you are the members and it is your Society. To say that the Society needs your help misses that point. It is up to you to join in the work of conservation, to take part, to get things going. As individuals we are relatively impotent, but as members of a growing and increasingly powerful Society we can have a great deal of influence on the world. Our success, however, depends on the efforts of individuals and there is much that needs doing. Even at our present membership level of just over 5000 we still need help in a huge variety of ways. We rely on one enthusiast to organize our buffet suppers at London meetings. We rely on the work of volunteers to administer our local groups in Bristol, Chester, Edinburgh, Oxford and Cambridge. We need volunteers to start our new Brighton Group. We need help placing our Mountain Gorilla collection boxes. We would love to hear from anyone who can get our posters displayed in libraries, supermarkets and especially in builders' merchants - sorry minimum 10 posters placed please!

Soon after joining the Society I

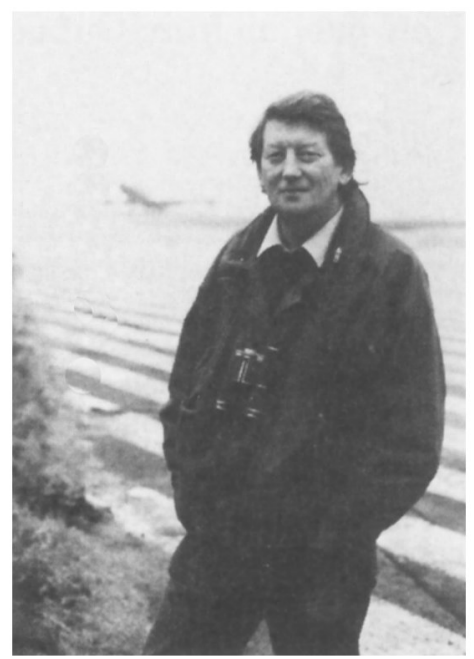

had an invitation from the Chancellor of the Exchequer to meet him at Lancaster House. There were, of course, several hundred others there as well, which was a pity, but they did include the Home Secretary, the Minister for the Arts, and famous Ronnie Corbett, who stood to make his speech. The Chancellor outlined his proposals to promote GAYE (Give As You Earn) and Mr Corbett hit the nail on the head by saying that if he wanted to give to a charity of his choice it would be $£ 3$ from him and $£ 1$ from the Chancellor. Mr Lawson claimed to be the only Chancellor in history to call a seminar to try to give away money. Brief details of the scheme can be found on page 246. Sir John Raisman of British Telecom promised to double the amount donated by anyone who works for BT. So in this case a GAYE scheme giving $£ 3$ a month (or week!) to the FFPS would actually produce $£ 7$ for the Society.

Finally, I would like to thank all of those members who were kind enough to write with their good wishes on my appointment. I'm doing my best.

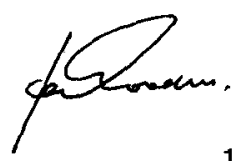

